\title{
Fish-farming, including farming of other organisms of economic importance
}

\author{
Convener's report of an Informal Session, held on September 11, during the \\ International Helgoland Symposium 1969
}

\author{
G. HeMPEL \\ Institut für Meereskunde an der Universität Kiel; Kiel, Germany ( $F R G)$
}

\begin{abstract}
PREFACE
The International Helgoland Symposium 1969 was held under the general theme "Cultivation of marine organisms and its importance for marine biology" (in the text quoted as "Symposium"). In conjunction with the Symposium an Informal Session (quoted as "Session") was arranged on farming of fish and other economically important marine organisms. It was the purpose of the Session to exchange information both biological and technical - on marine aquiculture and to link the particular problems of farming of fish, molluscs, and crustaceans with the biological aspects of cultivation of marine organisms. The Session was attended by more than 50 scientists; the list of participants is presented on pages $463-465$.

The convener had invited a number of experts to review their work in brief, by correspondence. These reviews served as background information and as a basis of discussion. Some reviews were presented at the Symposium and have been published in Helgoländer wissenschafliche Meeresuntersuchungen, Volume 20 (1970). Nevertheless, major items of all the reviews will be summarized in this report. The free flow of information and opinions in the discussion was one of the major merits of the Session. The principle aim of this report is to present as much as possible of the information provided. In order to facilitate further contacts between workers in the field, wide reference is made to the participants. As notes and records of the Session are not complete, the Convener must apologize in advance for any omissions or mistakes.
\end{abstract}

\section{INTRODUCTION}

As an introduction to the Session, the Convener mentioned 3 major lines of activities related to the controlled raising of economically important marine organisms. The ability of the sea to produce all kinds of fish has been praised in the literature and art 
of all periods of culture. However, harvesting the sea has always been regarded as hard and dangerous work which often fails to provide sufficient catches. The difficulties in catching fish and storing them for long periods resulted in the establishment of fish farms. A second line of activity involving the artificial raising of fish, is the attempt to improve the recruitment of natural populations of fish by restodking with larvae and young fish which have been reared in fish hatcheries. Thirdly, the understanding of the biology of fish depends partly on laboratory experiments in which fish, in particular the early stages, are reared under controlled environmental conditions which include those of food and predators. These three lines have different objectives which will be discussed in more detail. They have several common methodological and biological problems. Fish farms and hatcheries, although originally developed by trial and error, must in future rely upon the scientific results of laboratory experiments which, in turn, will profit from the experience gained in practical enterprises.

The exchange of information between workers engaged in the three lines of cultivation is limited. There are very few fields in marine research which, to a similar extent, are dependent upon technical skill and experience as is the cultivation of marine organisms. It was, therefore, one of the major objectives of the Session to bring into contact biologists interested in fish farming industry and hatcheries, and academic workers engaged in laboratory experiments. Although leading experts of many countries attended the Session, it was deplored by many of the scientists participating that fish farming activities in Great Britain and the USSR. were insufficiently represented at the Session.

\section{FARMING}

The maintenance and feeding of fish and shellfish in brackish water, lagoons, and ponds, in order to have fish of high quality available in most seasons of the year, is an ancient industry around the Mediterranean and in the Far East. Generally, not the whole life-cycle is under cultivation, but young stages are collected from the sea or those which penetrate naturally into cultivated habitats are kept there by closing the entrance after penetration. Man's activities in farming fish consist mainly in the provision of food; control of emigration, predators, and competitors; and in harvesting at a predetermined time.

In oyster and other shellfish farming the following measures are most important: provision of suitable substrates for settling; appropriate thinning of spat; and transfer into water with optimum conditions of food and temperature.

Marine fish farming has long been of limited importance and has not attracted much scientific interest, however, within the last decade mariculture has become popular. In the Far East, the development of raft culture for oysters and of net cages for yellow tail and other fish have been break-throughs in two major fields of inshore water farming. In Europe, mussel culture at Vigo and the successful experiments in the rearing of flatfish by SHELBourne (1970) and his collaborators have become famous. Similar activities have developed in the United States where major emphasis has been laid upon the culture of shrimp and crab. 
This new development has one of its main roots in the increasing demand for high quality, luxury sea food. The natural supply does not satisfy this demand everywhere, and overcropping of natural resources is a great danger. For many countries, particularly those in the tropics and subtropics, marine culture could become an important export. However, it should not be forgotten that aquiculture is already playing an important role in satisfying the demand for animal protein in several countries. Recent rough estimates by FAO report an annual production of $4,000,000$ tons - combining marine and freshwater culture. The potential increase is very high, perhaps 5-fold in the next decade. The greatest potentiality lies in the tropics, for it is there that one finds most of the input of solar energy, and those areas have the greatest number of people who are in need of supplementary protein. Although countries in the temperate zone are faced with serious disadvantages such as seasonal changes in temperature and primary production; shortage of unpolluted water; higher costs of land and manpower; certain kinds of aquiculture appear to be profitable for them, and it is hoped that the skill developed in those enterprises and in scientific studies can help tropical countries to extend and modernize their aquiculture. In future, tropical laboratories should make use of their particular climatic advantages and, therefore, play an increasingly important role in the furtherance of marine aquiculture by instigating wide programmes to study marine organisms of contemporary or potentially economic importance and develop techniques to complete the entire life-cycle in captivity and, eventually, to carry out selection and breeding to improve the stock of those species which appear to have the best economic potential in an aquicultural scheme. This was exemplified in the discussion by HeLfrich from the BCF laboratory on Coconut Island, Hawaii.

The increasing interest in the various aspects of fish farming is a challenge to marine biologists. Although, among scientists, there exists considerable apprehension towards widespread futuristic propaganda for the feeding of mankind by the products of mariculture; the direct scientific benefits derived from fish farming are recognized, in the same way that in fisheries biology the development of a new industry initiates further research in specific fields. Money becomes available for basic studies which are related to fish farming and a new market for well-trained marine biologists becomes available at a time when - in several countries - the output of postgraduates is higher than the number of positions vacant in traditional fields of marine science.

Fish farms can provide scientists with data of food input conversion, growth, and harvest which might permit the development of models based upon fishery statistics which would be comparable to the mathematical models of population dynamics. Monocultural farming, such as the raft culture of molluses and algae in the Far East, provide model-like conditions: while growth is good at the exposed outer parts of the raft, water exchange, abundance of food and, hence, growth of oyster and mussels is reduced in the centre of the raft. A quantitative description of this relationship would permit a better picture of food demand and food conversion and might lead to improved design of the rafts. On the basis of measurements of abundance of phytoplankton, filtration rate, and food conversion, it would be possible to decide for each locality whether, under given market conditions, culture of oyster or edible algae would be advisable. 


\section{HATCHERIES}

With the increase in sea fisheries during the second half of the last century there was growing concern about the reduction in spawning potential of commercially important stocks of marine fish. The initiative of fishermen and administrators established sea fish hatcheries in North America and Europe. Many millions of yolk-sac larvae of cod, haddock, plaice, and other food fish were released into the sea every year. At present, a routine release programme for cod is still in operation at only one European station (Flødevign, Norway). All other hatcheries were closed down after it was recognized or assumed that later recruitment to the fishable stock is hardly influenced by the addition of young larvae to the wild population. Such measures may lead to restocking small enclosed habitats only under special conditions of extremely low spawning potential. Nowadays, some scientists see good reasons to reconsider the issue in view of the revival of the anxiety concerning the adverse effect of present high rate of exploitation, which brings down the spawning potential of fish stocks to a very low level. It is for those reasons that Japanese laboratories again began release programmes, partly as a by-product of their activities to rear fish fry artificially as a supply for fish farms.

Early attempts to rear fish and shellfish from the egg stage were unsuccessful in most fish farms. The planktonic stages of fish and shellfish live in an entirely different ecosystem to that of the juvenile and adult demersal stages, and it has proved to be very difficult to copy and control the planktonic environment. In recent years, however, new attempts have been made in various countries to overcome the technical difficulties involved in rearing early stages of fish, crustaceans, and molluscs; and nowadays, it appears to be possible to have the complete life-cycle of some commercially important marine animals under hatchery control. This fact provides the possibility of selective breeding for high quality, fast growing, and resistant, marine "domestic" animals.

\section{LABORATORY STUDIES}

Experimental rearing of marine fish has been carried out for the last 100 years, and such experiments have served various purposes. Hatching of fish eggs was one of the means used to establish identification keys for marine fish eggs and larvae. For separation of stocks, meristic characters are widely used. It seemed necessary, therefore, to find out whether, and at which ontogenetic stage, the number of vertebrae, myotomes and fin rays are influenced by environmental factors. The effect of temperature, salinity, and light on incubation time, growth rate, and survival was studied intensively. For the development of advanced techniques for hatcheries under controlled experimental conditions, information on food conversion and trophic relationships of fish larvae, as well as data on vision, feeding behaviour, and on the optimum abundance and size composition of food plankton were indispensable. On the other hand, the experience assembled in hatcheries, particularly in those which operate on an experimental stage under scientific supervision provided most useful information on 
the early life history of fish and on the effect of overcrowding and other artificial conditions. A detailed review of the results of experimental approaches towards an understanding of the life history and ecology of the early stages of fish was given by BLAXTER (1969). Rearing of fish eggs and larvae and of certain invertebrates and algae as test organisms for measuring the effects of pollution is at present being developed and may become an important field of applied marine biology. Laboratory studies and tank experiments were also carried out for measuring food conversion and growth of juvenile and adult fish under various environmental conditions.

\section{DISCUSSION ON FARMING OF FISH}

During the Session, three aspects of fish culture received particular attention: food requirements, fish culture in cages and other net confinements, and behavioural aspects in rearing the early stages of fish.

\section{Food requirements}

HARADA, who presented a review of Japanese fish culture at the Symposium (HARADA 1970), described in detail some aspects of feeding sea fish in farms. In Japan, the major foods used to raise yellow tail are fresh or frozen fish, especially sand eel, anchovy, horse mackerel, common mackerel, and saury. For optimum growth of young yellow tail daily rations of up to $20 \%$ of body weight should be provided in summer conditions $\left(25^{\circ}-31^{\circ} \mathrm{C}\right)$, in winter conditions $\left(5^{\circ}-16^{\circ} \mathrm{C}\right)$ and for older fish, $5 \%$ would be sufficient. $6-7 \mathrm{~kg}$ of trash fish at a price of 4-10 US cents per $\mathrm{kg}$ are required to produce $1 \mathrm{~kg}$ of yellow tail worth $0.80-1.60$ US $\$$. The total production of yellow tail cultured was 27,000 tons in 1968 , culture of other marine fishes - mainly red seabream - amounted to 400 tons. At present, culture of yellow tail is increasing very rapidly.

In feeding experiments with rainbow trout in brackish water of the Western Baltic Sea, Koops \& Tiews found, when using pellet food, conversion factors of 1.7-1.9 for fish of $100 \mathrm{~g}$, the factors being somewhat higher in larger fish. Trout grew from an initial weight of $50 \mathrm{~g}$ to a final weight of $600 \mathrm{~g}$ in 7 months. It appears possible to have two to three crops per year which produce marketable fish of $250-300 \mathrm{~g}$, and the total crop $/ \mathrm{m}^{2}$ can be increased to $40 \mathrm{~kg} /$ year. German experiments in the feeding of rainbow trout in brackish water cages now concentrate on finding the optimum formula for pellets with respect to aminoacids, total protein, and vitamins.

ODum (1970) analysed quantitatively the role of Mugil cephalus as a feeder of phytobenthos and detritus. The food requirements of Chanos and other warm water species, kept in ponds in East Asia, were reviewed by LiNG (1967). Experiments on the artificial feeding of Mugilidae by VALxeT et al. (1970) showed that juveniles of Mugil auratus and $M$. capito change at about $30 \mathrm{~mm}$ length from nematodes to diatoms. Intestinal flagellates are additional, important food items. The juveniles grow better on protein-rich food, while adults do better on lower protein content. Addition of urea at 
a concentration of $4-8 \mathrm{~g} / \mathrm{l}$ reduces the loss in weight in starving fish. During the first week of starving, young Mugil of $800 \mathrm{~g}$ did not lose any weight if $4 \mathrm{~g}$ urea per 1 was provided, urea is used as a fertilizer in ponds in India. The best conversion factors were found at medium levels of daily diets (about $4 \%$ of body weight/d). The addition of cellulose as ballast reduced the conversion factors for assimilable food. Aoron (see contribution by Cowey et al. 1970) in his experiments with O-group plaice, found a linear increase of growth rate when using the protein content (mainly casein) of food paste. Optimum content was at about $60 \%$, while in other fish the optimum was somewhat lower. Conversion efficiency for protein appears to be lower in plaice than in other fish, possibly some of the protein is transformed into lipoids. Turbot is the only flat fish of the North Sea with a high growth potential. FLücHTER achieved annual weight increments of $100-175 \%$ in older fish, but O-group turbot grew from 0.3 to $10 \mathrm{~g}$ in 55 days. Growth in tanks was four times better than in the open sea. There are two major disadvantages to these species: They are selective in feeding and do not spawn in tanks. Turbot larvae and juveniles are difficult to find in the North Sea.

VALlET et al. (1970) also studied the effect of salinity on conversion and growth in Mugil; both were best at $20 \% \mathrm{O}$ S, thyroid activity being lowest at $12 \% \mathrm{~S}$. It was debated whether the improved growth and conversion at $20 \% \mathrm{~S}$ might be due to a decrease in locomotory activity of the fish. The effect of salinity on growth still remains an open question. The phenomenon of faster growth in salmonids and other fish after emigration into the sea has been attributed as much to better feeding conditions as to salinity itself. Feeding experiments with trout (by TIEws) and with Tilapia (by KRISTENSEN) did not indicate better growth in brackish water, while WEBBER found some increase in growth rate in catfish kept in brackish water; further studies by NELLEN are in progress. LeRAY when referring to the Danish brackish water farms for salmonids, pointed out that although growth rate might increase with salinity, conversion might be better at lower salinities.

Pond culture of catfish in brackish and fresh water ponds in the Southern States of the United States, particularly in the Mississippi Delta, is receiving increasing attention. According to WeBBER, production of catfish produced by pond culture was expected to exceed wild catches by four times in 1970. There is an increasing export of catfish products to the Northern United States. Artificial feeding by pellets seems to ensure optimum growth, because the composition and content of protein can be adjusted to the particular needs of the fish. Behavioural studies should lead to an adjustment of the provision of food rhythm to the feeding rhythms of the fish under given light conditions. For demand feeders, a feeding apparatus to be triggered by the fish, seems to be the most effective and economical in food. The specific weight of pellets has to be adjusted to the particular types of feeding behaviour. Yellow tail pick food items from the surface, mackerel snap food sinking in mid-water, while file fish require food items which are almost buoyant (Fujrya \& Harada). For cage cultured trout, pellets of high specific weight are preferable; lighter pellets being pushed through the meshes due to the high swimming activity of trout (Koops). No single food items (pellets) but loaves of a food paste are best suited to eels, which will then aggregate and stimulate each other to feed. The optimum composition of pellets varies from species to species and between age groups. Leray, using a given diet, experienced good 
growth in one species but lethal results in another. Reference systems used in terrestrial animal husbandry cannot be applied when feeding fish. In the discussion, no clear answer to a suitable reference diet could be formulated. The aminoacid composition of the fish in question may be used, but it is still debatable whether the food should have the same composition, as digestion of some compounds might be insufficient. Furrya experienced $30 \%$ better growth by adding a protease enzyme to the pellets.

To date, the Japanese culture of yellow tail is based entirely on the provision of trash fish as food, but with the rapid expansion of marine fish culture in Japan much experimental work is going on to replace such food fish by other products, i.e. soya beans, fish meal, or yeast cultivated on waste petroleum or wood pulp. Eels experimentally fed with a mixture of $50 \%$ artificial protein and $50 \%$ natural protein had an oily taste and the Japanese Ministry of Health would not accept them for public consumption.

In addition to protein contents and amino acid composition, other factors seem to play an important role. The best two kinds of food pellets used by Tiews and Koops in their experiments with rainbow trout differed considerably in their protein contents $(31 \%$ and $46 \%$ ) but had high contents of vitamin $A$ and $D$ complex; the search for optimum binders must receive more attention. The binding capacity of some applications of gelatine is better in seawater than in fresh water. Binders make up a considerable part of the total cost of fish food, and they decide the percentage loss of food particles. Fujry achieved good results with the addition of gluten which, however, is considerably more expensive than alpha starch. Gluten is used for feeding carnivores, alpha starch is common in herbivorous pellets. WeBBER stressed that brewery wastes are an inexpensive source of vitamins which are readily available in most parts of the world. When fish cultivated in farms are processed, about $50 \%$ offal is produced, which should be re-cycled by hydrolysis for a well balanced fish food. Experimental brackish water pond culture in Germany aims at the use of the by-catch of shrimp fisheries (TrEws). The provision of food should depend upon the amount of activity of the fish in order to avoid overfeeding. Little is known about the behavioural aspects of optimum design of confinement or about stock density, $i$. e. the minimum space required per fish at a given temperature. In eels and other fish which find their food by smell, stock density should not be too low, as mutual stimulation plays an important role and assists the individual fish to find food. According to Koops, minimum stock density in eels is $1 / 2-1 \mathrm{~kg} / \mathrm{m}^{2}$. After transplantation, eels learn to feed within $5-20$ days and it is then an advantage to have some pretrained fish in the pond.

In the schooling of fish, learning and, therefore, adaptation to certain feeding conditions, is relatively fast; to date, no successful method has been developed to farm fish which have territorial behaviour.

The behavioural and sensory physiology of feeding is not known sufficiently even for some of the economically most important fish. In ponds and cages, illumination may differ considerably from the conditions of natural habitat. The optimum illumination has to be found and it might be worth while to carry out experiments using various illumination rhythms in order to increase knowledge of feeding activity. 
Fish culture in cages, floating nets, and netted bays

For many centuries, ponds have been the only common method for cultivation of fish. In recent years, various kinds of net cages have been developed both in fresh water and in coastal areas, and during the Session, experiences from Japan, U.S.A., and Germany were blended together. HARADA reported on the growing success (since 1954) of culture of yellow tail in nets suspended on rafts of the type originally used in oyster culture. The largest nets in use are $20 \times 30 \times 3 \mathrm{~m}$ : the smallest $3 \times 3 \times 3 \mathrm{~m}$. $5-50 \mathrm{~kg}$ of fish can be kept in $1 \mathrm{~m}^{3}$ of water, depending on temperature and water exchange. Some of the major problems are the increasing spoilage of water and the sea bed in bays which are permanently used for cage culture, infestation by parasites and epidemic diseases are also increasing.

The advantages and disadvantages of net cages over ponds are - according to HARADA: The net cage can be constructed very easily, rapidly and economically. The exchange rate of seawater in the cage is high, and higher density of cultivation can be expected with normal growth. The fish in the cage can be picked up quite easily, whenever desired. This is not only favourable when harvesting but is also very convenient for treatment of disease when necessary. Net cages can be established in any place, even in open sea areas. They are easily handled to move to sheltered places and/or to be settled down to deeper levels in the emergency conditions of rough water such as a typhoon, therefore, damage can be avoided with ease. There is a free choice of the size of net cage according to the farming situations. The net cage may be weak against solid floating materials in the sea, but an application of double nets may be acceptable to avoid damage. The net is easily contaminated by various kinds of fouling organisms, fish faeces, waste oil, and silt, and the renewal of the net will be required every one to three weeks in order to maintain good conditions of environment. The contaminated nets can be renewed for further use by washing with a high pressure jet of water.

In yellow tail culture, mesh size is adjusted to growth of the fish. The following mesh sizes are in use:

Body length of yellow tail
$1-3 \mathrm{~cm}$
$5-10 \mathrm{~cm}$
$15-20 \mathrm{~cm}$
$30-40 \mathrm{~cm}$
$45-70 \mathrm{~cm}$

Mesh (knot to knot length)
$0.5-0.6 \mathrm{~cm}$
$0.7-0.8 \mathrm{~cm}$
$0.9-1.0 \mathrm{~cm}$
$1.2-1.8 \mathrm{~cm}$
$2.0-3.0 \mathrm{~cm}$

Normal net cages are made from twisted synthetics or plastic-coated, metal wire. Most of the trout farmers use mesh size of one tenth of the length of the smallest fish. TIEws reported on German experiments with net cages of $3 \times 5 \times 2 \mathrm{~m}$ (smaller cages being less useful) hanging under a pier in a brackish water fjord of the Western Baltic Sea. Co-operation of experts on ship fouling is required to reduce the serious fouling of the nets in some coastal areas. In net cages, current velocity has to be controlled, as too high velocities put great stress upon the fish and might reduce growth; lack of current results in fast sinking of food. 
Confinement in cages causes considerable changes in behaviour and morphology of fish. TIEws reported on trout which grew in height and became fatty when kept in cages. The same may happen if activity is reduced by tranquilizers. Trout in extreme confinement, but very high flow of water, showed good growth and no extreme fattiness (WEBBER). While in the cages exercise of muscles is reduced, race-ways force fish to exhibit high activity.

Projects to close bays for extensive fish farming are in progress, especially in Japan. Recently, a bay of $10 \mathrm{ha}, 18 \mathrm{~m}$ maximum depth $\left(750,000 \mathrm{~m}^{3}\right)$ was closed by nets. In addition to the tidal currents, pumps were installed to ensure sufficient exchange of water. Such bays, as well as large netted areas in the open sea, might serve for the culture of tuna.

FujIYA also reported experiments which involve the conditioning of trout, now taking place at the Marine Propagation Centre of Yoshima. Trout are placed in a net cage within a small marine inlet. Buzzer signals of $200 \mathrm{~Hz}$ are given just before feeding, within about two weeks fish are trained to come to the feeding machine as soon as they hear the signal. Then the cage can be removed and the fish are completely free to move around and feed naturally, but artificial feeding in combination with the buzzer is continued until harvesting, which is achieved by a lift net at the feeding place. The method described saves labour, food, and installations, and results in good growth. In experiments with steelhead trout in Puget Sound a buzzer of $450 \mathrm{~Hz}$ was used (WEBBER). In the Japanese and American studies the final rate of catch was not yet satisfactory as some fish seem to emigrate or become more attracted by natural food than by the relatively fast-sinking food pellets.

\section{Genetical problems and larval studies}

Peters provided a résumé on some genetical problems in fish culture, particular attention being paid to the effects of hybridisation. Hybrids of various fresh water fish, especially salmonids and coregonids, have long existed but not very much work has been carried out on the hybridization of marine fish. In Japanese experiments with red and black seabream, the hybrids had a growth rate intermediate to the parent species, but they showed higher resistance to unstable environmental conditions. Growth rate and condition factors were better in hybrids of parrot fish than in the parent species, and in hybrids of flounder and plaice which showed low mortality and reproduced successfully (Dannevig, Danielsson). Peters further pointed to the dangers of inbreeding in fish cultures. Selection and breeding should be designed to meet particular requirements of the market, to improve food conversion and resistance to parasites and diseases, as well as to unfavourable environmental conditions. Nongenetical maternal influences upon the survival of eggs and larvae have been reported by several fish farmers; but, in sea fish, little scientific work has been carried out (HEMPEL). Reference must be made to the discussion of genetical problems by SIMON and Donaldson at the conference on Marine Aquiculture, Newport, Oregon, in May, 1968 (MCNeIl 1970). At the same conference, Sinderman discussed the importance of control of diseases and parasites. This problem - although crucial in many experi- 
mental and commercial cultivation activities - was mentioned only briefly at the Session.

Questions upon the rearing of fish larvae were discussed briefly as they had been the subject of several earlier meetings, i. e. those of the International Council for the Exploration of the Sea. At the Symposium, Fonds had described the successful rearing of gobiids making reference to the need to sort plankton in order to provide the right choice of food for each developmental stage, he also referred to a method of washing the larvae. Helfrich and his colleagues at Coconut Island, Hawaii, have started an extensive programme of behavioural and methodological studies by rearing various fish and crustacea in plastic bags which hang in tanks. Davis offered the facilities of his firm at Boca Raton, Florida, for any rearing experiments.

BLAXTER believes that round, black-walled tanks are best for rearing fish larvae. The dark background provides good contrast against the food, homogeneous illumination by round lamps leads to homogeneous distribution of food organisms. He found that in clupeid larvae, regardless of initial stock density, one obtains only a given number of larvae. Diurnal changes in illumination, and possibly also in temperature, reduce mortality. The adverse effects of sensory deprivation when rearing fish larvae was the theme of his contribution to the Symposium (BLAXTer 1970).

RosentHal had started experiments using cycling changes in temperature. Daily fluctuations of up to $2.5^{\circ} \mathrm{C}$ are tolerated by herring larvae and appear to have a positive effect on the growth of the embryo, only the first stages of development seem to be more sensitive. As such fluctuations might well occur in fish farms in littoral areas or at the effluents of power plants, experiments with cycling temperature are particularly important. FLÜCHTER, however, pointed out that herring eggs might be particularly tolerant to changes in temperature (some groups of herring spawn at the bottom of the littoral and uppermost sublittoral zone) while pelagic eggs, e. g. sole eggs, are rather sensitive to temperature fluctuations.

In several Japanese laboratories, rearing work is going on using yellow tail and other species, eggs are either collected at sea or, preferably, taken from females in capture. Frequently, activation of ovulation is carried out by intramuscular application of hormones. Normally, a dry or semi-dry method of artificial fertilisation is used. In yellow tail the incubation period is very short, and food demands change considerably within the first month of life. HARADA (1970), in his contribution to the Symposium, produced a feeding table which shows the developmental periods during which certain kinds of food, such as oyster larvae, rotifers, copepods, etc., will be accepted by the larvae. Feeding takes place twice a day in summer, and once a day in winter. One aspect of the larval ecology of a pomacentrid fish was used by HELFRICH to illustrate the way in which a thorough knowledge of the natural life-history can be extremely helpful in the successful rearing of delicate larvae in the laboratory. An analysis of the stomachs of larvae revealed a change in diet seven or eight days after commencement of feeding, from smaller, less mobile nauplii to larger copepods which contain more food energy. This knowledge was essential to the successful rearing of this species in the laboratory. 


\section{DISCUSSION ON CULTIVATION OF BIVALVES}

Fujrya, in his contributions to the Symposium (Fujry 1970) and to the Sessionreported on oyster farming in Japan, which has a tradition dating badk to the early 17th century. Among the seven species under culture, Crassostrea gigas is the most important one, and produces 45,000 tons of meat per year, $65 \%$ of this production in the Hiroshima area. The methods are based mainly on experience rather than on research.

At $20^{\circ} \mathrm{C}$, gonads of C. gigas ripen in May-June. The larvae settle after 10-14 days of pelagic life, at that time spat collectors (usually shells of Pecten) have to be exposed. Earlier exposure of the collectors leads to heavy fouling by barnacles and algae. On the other hand, oyster farmers try to collect spat as early as possible in order to take maximum advantage of the warm season for the growth of young oyster. On the basis of climatological information, a forecasting system has been developed by the Japanese Government to indicate the best time for collection of spat. Collectors are exposed just under the surface where spatfall is heaviest, because barnacles usually settle in slightly deeper layers. Selection of growing sites is dependent upon shelter against rough sea; vicinity of oyster beds; presence of tidal currents; optimum salinity and high temperatures, as well as high primary production. Pollution is also an increasing threat to oyster culture in Japan. About 20-30 oysters survive on each shell independent of the original number of spat. After some months the Pecten shells, which hang one above the other, have to be spaced.

Three types of structure are used to keep the wires with shells suspended. Floating longlines attached to poles are used along the exposed coasts of Northern Japan. $\mathrm{Racks}$ are erected in the shallow water, however, when using this method all oysters are submerged at high water only. Harvesting takes place after 1 or 2 years, the later case hardening of the young oysters reduces mortality under unfavourable conditions. More recently, $\mathrm{r}$ af $\mathrm{ts}$ of bamboo poles have been introduced into the sheltered waters of central Japan and in the Inland Sea. Each raft measures $16 \times 8 \mathrm{~m}$ and carries 500-600 wires, and a distance of 5-10 m is kept between the rafts. Most oysters are harvested after 1 year, but $3-5 \%$ of the 1 year old oysters are selected by their shape and raised separately in flat cages and are later sold as expensive giant oysters. Total production per raft is $2-4$ tons of oyster meat, yielding US $\$ 3,000-6,000$. Investment for a raft costs about US $\$ 400$.- and the optimum annual yield is 58 tons/ha.

In Japan, the major biological and technological problems of oyster culture are the control of predators (star fish and oyster driller), competitors (mussels etc.), parasites, and pollution. Red tides in spring and autumn were mentioned as further major obstacles to successful culture. Much work has to be done in order to simplify the laborious culture technique. Recent developments in the cultivation of Ostrea edulis and mussels in the northwestern part of Spain (Galicia) have been described by Frgueras (1970). As natural substrate for oyster settlement becomes more and more scarce, artificial substrates have to be used. Usually, young oysters imported from Britanny, are cemented onto culture ropes suspended on rafts or fixed on fibrocement plates and deposited on the sea bottom in the culture area. 
Since the introduction of raft culture, production of bivalves has increased considerably. Floating rafts are now used extensively - i. e. for cultivation of pearl oyster and edible oyster in Japan and also for oyster and mussel culture in Spain. The major advantage of rafts, when compared with fixed installations, is the independence of the former from tidal changes in sea level which keep the bivalves permanently under good feeding conditions. Furthermore, rafts can easily be transferred, according to seasonal changes in temperature and food supply.

BøHLe reported upon an improvement of Spanish style raft culture for blue mussel (Mytilus edulis) by use of a new technique for thinning the spat: a net bag has been developed and produced in collaboration with Landheim Veveri, Skreia and Dena Bandfåbrikk, Gjøvik, Norway. The bag is woven as an endless net tube from polypropylene fibres with mesh of $6.5 \times 12 \mathrm{~mm}$ (or $6.5 \times 5 \mathrm{~mm}$ ) and a diameter of 3.0 and $3.8 \mathrm{~cm}$. The tube may be cut to any length, and one end can be closed by a knot. The length normally used in the Norwegian experiments is $3-4 \mathrm{~m}$. A raft of $7 \times 5 \mathrm{~m}$ can carry 100 bags and may yield 2.5-3 tons of mussels. Mussel spat is collected in the usual way on ropes or wires, suspended from rafts, stripped off, and put in the net bags. When these are submerged in seawater, the spat begins to crawl through the mesh and fasten themselves onto the outer side. The polypropylene bag is strong enough to carry the mussels until harvesting, 1 to $1 \frac{1}{1} / 2$ years later. In Norwegian waters, particularly in Bergen and Oslo Fjord, the most convenient season for transplanting seems to be in August to September, when the sea temperature is still high (up to $20^{\circ} \mathrm{C}$ ) and the spat is $15-25 \mathrm{~mm}$ long. Under such conditions, complete crawling to the outer side of the net bag takes place in a few days. At some localities the mussels attained marketing size of $5-6 \mathrm{~cm}$ in 14-16 months after "planting" the spat. The net bags, which look like wide-meshed stockings, have been described in more detail by BøHLE (1969). Although the method proved to be successful, some deficiencies were mentioned which apply to most kinds of mussel culture: insufficient control of predators (Asterias rubens) and competitors for space and food (Ciona intestinalis); new spatfall on the transplanted mussels; heavy fouling by algae, particularly in polluted, eutrophic waters; incrustation of older mussels by barnacles; and damage by drifting ice. The optimal number of mussels per $m$ of net bag is difficult to determine as it yaries from locality to locality depending on food, oxygen, and temperature conditions.

Fujrya reported on the growing economic interest of cultivation of Pecten. Attempts have been made to cultivate this highly priced, mobile bivalve in various parts of Japan and also in the United States and France.

In Japan, as in many other places, overcropping of wild oyster beds endangers the production of a sufficient supply of spat. The same is true for other bivalves, particularly pearl oyster and Pectinidae. Japanese attempts to rear bivalve larvae have not yet reached mass production stage. Lucas reported on successful experiments by the marine laboratory of the Faculté des Sciences, Brest (France), supported by CNEXO. For rearing the larvae, a closed system was used with seawater sterilized by filtration on a Millipore filter $(0.2 \mathrm{~mm})$. Spawning was induced by thermal stimulation; the adults were not previously conditioned, but were picked from their habitat during the normal period. The water was changed every day when the larvae were swimming, 
but only every other day after settlement, and juveniles only once a week. The food used was Monochrysis lutheri or Isochrysis galbana.

Good results were obtained with some species of Veneridae, i. e. Venus verrucosa, $V$. striatula, Venerupis aurea, V. pullastra, and V. rbomboides. Spawning is not easy to induce in the commercial Venerupis decussata and, therefore, no larvae were obtained. In Pectindae (Chlamys varia and Pecten maximus) the first larval stages only were kept alive, some of them were abnormal, and none reached metamorphosis.

In a contribution to the Symposium GRUFFyd \& BEAUMONT (1970) related a high percentage of abnormalities to Pecten larvae with too high concentrations of eggs and/or sperm. Similar experience with larvae of Pecten maximus was reported by GRUFFYDD. While it seems relatively easy to obtain eggs and sperm at any time of the year through conditioning of the adults, spawning products do not seem equally viable in all seasons. By the rearing technique of WALNE larvae grow fairly well at first but, a few days before metamorphosis, growth comes to a full stop and high mortality is observed, possibly as a result of inadequate food supply. GruFFyd also outlined the general programme of rearing the early stages of other commercially important bivalves at Menai Bridge; this work is directed to provide for studies upon the histology, biochemistry, and development of larvae.

WALNE (1970) found fluctuations in growth under standard culture conditions which were positively related to variations in turbidity of the water, upon the occurrence of Phaeocystis pouchetti, and upon the content of zinc detergents and pesticides in the water. Bacterial diseases are major hazards. Further laboratory experiments must check upon the effects of some factors which are so far unsuspected, but which may affect growth and survival especially by interaction of various minor factors. Commercial culture of oyster larvae depends on natural products which, inevitably, will vary in their quality, but the more these can be standardized, the more reliable will be the success.

The provision of clean seawater for use in experimental tanks and aquaria becomes increasingly difficult because of pollution, therefore, the extensive use of artificial seawater was recommended. In such cases, as well as in closed systems with intensive filtration, shortage of some trace elements may be observed, that, however, seems to be more serious for rearing plant food organisms than for rearing bivalve larvae. Further problems arise from toxic compounds in some plastic materials etc. Reference was made to the Symposium contribution of Bernhard \& ZatTERA (1970), in which was demonstrated the toxicity of many common laboratory materials to phytoplankton. HELFrich reported on the apparent toxicity of tygon, plexiglas and polyvinylchloride to some larval forms of fish. However, PERsoone pointed out that in large scale rearing projects there is a limit in the extent to which precautions and cleanliness can be carried. 


\section{DISCUSSION ON CULTIVATION OF COMMERCIALLY IMPORTANT CRUSTACEA}

At the Symposium, SASTRY (1970) reported on the successful rearing of brachyuran larvae and Rice \&. Williamson (1970) reviewed the methods of rearing larvae of other decapod crustacea and gave their opinions upon the possibilities of applying those methods to mariculture. They consider it possible to rear most kinds of commercially important decapods (except palinurids) under laboratory and pond conditions, provided that the particular needs of the various species are fully known. In this respect, much further work seems to be needed before the complete life-cycle of marine Crustacea can be cultivated on a commercial scale. The discussion of the Session centred around past and present attempts to rear lobster and penaeids. Lobster-hatching practice - as reviewed by KENSLER - dates back to the $1880^{\prime}$ 's. At the turn of the century, about 20 laboratories were employed in producing lobster larvae (Homarus gammarus and $H$. americanus) in Europe and North America. Part of the lobster fry were released as larvae and others were reared to a larger size. Meanwhile, most of the hatching programmes have been abandoned because of (a) low survival rates of larval stages (i. e. 10-20\% during larval stages); (b) diseases and parasites; (c) cannibalism; (d) high cost of labour, and the relatively few larvae produced.

Reasons for being unable to maintain juveniles to larger sizes, were slow growth rates - 5 to 7 years to attain a commercial size of $450-500 \mathrm{~g}$; cannibalism in confined space (especially at the moulting period); as well as poor food conversion ratio and insufficient supplies of cheap food.

Only one station in Europe (Flødevign, Norway) is continuing its programme. In North America, the Massachusetts State Lobster Hatchery carries out research and mass production of lobsters - restocking coastal waters since 1951. At the Fishery Research Board of Canada, experiments are underway to introduce adults of Homarus americanus from Eastern Canadian waters into Fatty Basin (Vancouver Island, B.C., Canada) and to hatch and rear larvae to stock coastal waters of British Columbia.

The American lobster is one of the few commercially important species of which the entire life-cycle can be grown under laboratory conditions. K.ENSLER, however, stressed the point that, at present, with existing knowledge, commercial lobster culture is not feasible. He started a project to study eggs, larvae, and juveniles by laboratory experiments in order to obtain more knowledge about each larval stage, and about optimum requirements for growth and survival. At $20^{\circ}-22^{\circ} \mathrm{C}$, larvae were produced in four months, instead of the usual nine to ten months which are required for females to hatch eggs under local ambient temperatures of $6^{0}-7^{\circ} \mathrm{C}$. Larvae so hatched were reared at high temperatures (i. e. $25^{\circ} \mathrm{C}$ ) and showed very fast growth. Four larval stages at $25^{\circ} \mathrm{C}$ were completed in 9 days, compared to 35 days at $10^{\circ}-14^{\circ} \mathrm{C}$. The environmental requirements of the various larval stages are different. Further laboratory experiments are planned to ascertain for each larval stage: (a) nutritional requirements (size, kind, and abundance of food) and conversion rates; (b) upper and lower lethal temperature and salinity; (c) growth and moulting rates at various temperatures; (d) survival rates at different temperature - salinity combinations, etc.

As a side-line of the discussion, the off-shore lobster fisheries in the canyons of the 
continental slope along a considerable range of the US Atlantic coast were mentioned. The lobster caught at 100-600 $\mathrm{m}$ depth are much larger, but may not be growing faster than coastal lobster. Comparative studies into the larval development and growth of lobster from shallow waters and deep waters, and between European and American lobster seem to be advisable in order to find the optimum breed for further commercially orientated rearing experiments. The larvae of the American lobster are smaller and less variable in size than that of the European lobster, but it is still open to debate whether the difference is fixed genotypically or is produced by the higher rearing temperature used in the American experiments.

Attempts to culture penaeid shrimps in the United States were described by Webrer (1970) at the Symposium. He compared the American method with both earlier and recent Japanese activities. The traditional Japanese practice of farming shrimps is very similar to their methods of farming fish in ponds. Juveniles are caught in coastal waters and transferred into ponds artificially or by tides. The ponds are highly productive, yielding more than 1 ton/ha per year although little is done to eliminate predators and competitors. The modern Japanese methods, which are still in an experimental stage, begin with fishing for mature, fertilized females which liberate eggs soon after capture at $25^{\circ}-31^{\circ} \mathrm{C}$. About 1,000 nauplii per liter are kept in indoor tanks. The protozoa stages are fed with cultivated diatoms, the mysis stage requires zooplankton such as oyster and copepod larvae, Artemia nauplii, and rotifers. Ground molluscs must be fed in surplus to avoid cannibalism in post larvae. The production of postlarvae costs about 1 US cent each. After 10 days of postlarval life, juvenile shrimps are transferred into shallow $(60 \mathrm{~cm})$ ponds which have a sandy bottom. After a further 10-20 days, juveniles have reached $18 \mathrm{~mm}$ length and are ready to be used for restocking coastal waters - particularly those of the Inland Sea, or to be transferred into larger ponds (4 ha). Shrimps kept in the large ponds are fed for ten months on ground mollusc meat. In experimental ponds, yields of 10 tons/ha have been achieved.

Basically, American shrimp farming is similar to the Japanese method of pond culture. Optimum salinity increases from 20 to $30 \%$. The major causes of mortality are periods of $\mathrm{O}_{2}$-deficiency due to overfeeding the ponds without application of aeration. During the juvenile phase, water temperature should be $24^{0}-30^{\circ} \mathrm{C}$. In the Northern Gulf of Mexico, only 200 days per year optimum growth can be observed, while in Northern Honduras growth is very fast almost all year round, permitting three crops per year at a rate of 4 tha per crop.

In fenced-in bays which had been cleared of predatory fish by rotenon, implanted shrimps yielded $800-900 \mathrm{~kg} / \mathrm{ha}$ per year without additional feeding. In pond culture, pellets of fish meal, fish solubles and starch products (corn, rice, bananas) plus vitamins are used. At daily rations of $>5 \%$ of body weight the conversion rate decreases but growth increases up to more than $1 \mathrm{~mm} /$ day. Feeding is still an economic problem in American and Japanese shrimp culture. Shrimps seem to like a mixed food (portions of Tubifex are put into a feeding frenzy), but it seems impossible to train shrimps to become demand feeders. Shrimps do not school and do not induce each other to feed intensively. 


\section{DISCUSSION ON REARING OF FOOD ORGANISMS}

Representatives of all major systematic groups of organisms play a role in feeding one or the other marine animal used in aquiculture. Usually, only a few of those food organisms are cultivated, the majority being taken from the sea. Food is often supplemented by terrestrial products such as low quality animal and plant protein, and starch etc. Fish meal and trash fish are used extensively to feed adult and juvenile fish. Various methods for collecting or herding zooplankton are employed, as well as some artificial fertilization of embayments which lead to an enrichment of phytoplankton and benthic diatoms. Artificial production of food organisms is most important for the reliable provision of suitable foods for the early stages of artificially reared bivalves, crustaceans and fish. In its simplest form, this is carried out by the production of mixed cultures of phytoplankton in well-fertilized seawater kept in sunlight. The production of "green water" is widely used in Japan as the basis for cultivation of small zooplankton which is supplied as food for larval fish and shrimps. Chlorella and Chlamydomonas are the most common groups in those cultures. More sophisticated approaches to cultivation of micro-organisms, certain phytoplankton and zooplankton organisms have been described at the Symposium by various authors. At the Session, particular attention was paid to the mass production of Artemia salina.

SERENE and WeBbER reported on production on a commercial scale of Artemia salina in highly saline marsh lakes in Southern France, Japan, and the Bahamas. WEBBER referred to the soda processing facilities in the Bahamas, which pump water through the ponds. At sixfold salinity, maximum production was achieved, the population of Artemia was associated only with Dunaliella and two kinds of bacteria. According to SERENE, Japanese workers developed a method by which ponds are agitated for three weeks before they are inoculated with $A$. salina. After 20 days a large supply of Artemia fry is produced which can then be fed to elvers.

Indoor culture of Artemia salina is common in several places which rear flat fish. FL ÜCHTER produced $150,000 \mathrm{~A}$. salina per $\mathrm{m}^{2}$ within 14 days at $29^{\circ}-36^{\circ} \mathrm{C}$. A culture of flagellates, which requires certain bacteria, was fertilized by herring brine. $\mathrm{He}$ encountered certain difficulties in balancing the production of algae and growth of A. salina. Pure cultures were difficult to keep on Helgoland. BERNHARD reported on the successful culture of Artemia tetrasamas using a complexing agent. As a mixed and well-balanced diet is required by most juvenile fish and invertebrates, much more work is needed in the field of artificial culture of a wide range of food organisms. WALNE (1970), in a paper contributed to the Symposium, gave detailed information on the positive effect of feeding oyster larvae with a mixture of phytoplankton algae produced in pure cultures. In the Session, Harada reported on Japanese attemps to cultivate copepods of high nutritional value, and BjörNBERG described successful experiments in rearing copepods and Enteropneusta. She commented on the dangers of generalization about the possibilities of easy rearing of all kinds of marine copepods. Only species of the littoral and upper sublittoral are easy to rear. Cultured populations vary in their resistance, which is best at times of high reproduction. 


\section{MARICULTURE IN DEEP WATER, OPEN SEA AND INLAND}

The increasing number of power plants in coastal areas stimulate experiments in the use of the raceways of warm waste water for oyster and shrimp culture (GAUCHER). These raceways have a high exchange of water (up to ten times per $h$ ). The waste water carries large amounts of detritus and nutrients. Most of the zooplankton is destroyed by the pumps, and also by devices similar to small plastic balls which are used to keep the tubing clean. As soon as water exchange is slowed down, production of phyto- and zooplankton can be extremely good. In various places power plant effluents are used to fill and warm up ponds and small bays for fish culture (Webrer, Trews, BeLl); for details see GAuchER's contribution in MCNeIL (1970).

In many species, salinity is of less importance than is usually expected. In such cases it is more of an economical than of a biological relevance whether aquiculture should take place in fresh water or in brackish water; some species can be adapted to culture in seawater. FL ÜCHTER and LILLELUND experimented with rainbow trout. In this species, salinity tolerance increases during the juvenile phase but decreases once again when the fish matures. Yolk-sac larvae are very sensitive to salinities above $5 \%$, older larvae tolerate about $22 \%$, but a few specimens can adapt to full strength seawater if adaptation (at $20^{\circ} \mathrm{C}$ ) is performed stepwise with increases of $2.5 \% \mathrm{~S}$ every five days. The difference in tolerance seems to be genetically fixed, and should be used for selective breeding. All rainbow trout (Salmo gairdneri) reared in German trout farms are supposed to be the result of interbreeding of Salmo clarkii, S. shasta and S. irideus. Trout farming in seawater is of importance for those countries such as Germany, where good fresh water is scarce and land required for ponds is expensive.

Furthermore, there is some evidence that many fish can be adapted to higher temperatures and that they do not suffer from cutting out the arrest of growth in winter. Potential growth and final size seems to be considerably higher in several species than is normally attained in nature (WEBBER). Experiments with keeping oysters at $100 \mathrm{~m}$ depth off Hawaii showed that culture need not be restricted to shallow areas (HELFRICH). Bottom cages for salmon in deep water proved to be useful as such cages are then protected against wave action and thieves. In future, pollution and other obstacles to mariculture in coastal areas may lead to open-sea projects in spite of the higher costs of transport and construction.

FONDS, WICKSTEAD and WeBbER advocated marine fish culture for arid inland areas where desalinized seawater could be used for irrigation, and the highly saline water reservoirs could provide opportunities for culture of Artemia salina. 2,000 ha of salty marshes in Southern France are now used for fish farms, at present cultivating mainly eel and seabream, the latter grow to a marketable size of $200-300 \mathrm{~g}$ in 5-6 months (SERENE). The final success of this project will depend on proper monitoring of water quality, artificial food, and artificial breeding. Already, mariculture of various organisms has developed into an industry which will become an important element in projects for the multipurpose use of some lowlands, marshes, and estuarine districts. The combination of desalination plants, industrial chemical and power plants providing mariculture in ponds and raceways appears to be profitable. Mariculture should be linked with industry both for processing maricultural products (canneries, 
freezers) and landings of commercial fisheries, and for producing fish food partly by re-cycling the offal.

\section{CONCLUDING REMARKS}

The Session brought together information on recent trends of mariculture in several parts of the world. Although the information was not complete, and important aspects had to be neglected because of lack of time or of expertise, it was obvious that, in recent years, experience in cultivating marine organisms of economical importance has increased. Much work is still to be completed by biologists before aquiculture reaches the same level of efficiency and sophistication as that of terrestrial husbandry. Possible lines of future research could be: (a) Study of a large variety of species to find those which are suited for a given area and market. (b) Keeping the entire life-cycle under culture to carry out selection and breeding. (c) Search for suitable food organisms and inexpensive artificial foods for the various phases of the life-cycle. (d) Behavioural studies for the better design of encasements (such as cages, ponds etc., and of feeding techniques. (e) Studies on the application of hormones and other stimuli for maturation and spawning. (f) Studies into the prevention of diseases and parasites. (g) Evaluation of the merits of restocking marine habitats.

The lively discussion during the entire Session demonstrated the strong demand for exchange of information and opinions amongst scientists engaged in various lines of experimental and commercial cultivation of marine organisms. Several participants expressed their hopes that the FAO Fish Culture Bulletin will develop into a stock exchange of relevant information. It was recommended that, in a few years, FAO should hold a world meeting on mariculture. Thanks were expressed to the Biologische Anstalt Helgoland for arranging the Session and for the intention of publishing the convener's report of the Session.

\section{LITERATURE CITED}

Blaxter, J. H. S., 1969. Development: Eggs and larvae. In: Fish Physiology. Ed. by W. S. Hoar \& D. J. Randall. Acad. Press, New York, 3, 177-252.

- 1970. Sensory deprivation and sensory input in rearing experiments. Helgoländer wiss. Meeresunters. 20, 642-654.

BøHLE, B., 1970. Forsøk med dyrking av blåskjell (Mytilus edulis L.) ved overføring av yngel til nettingsstrømper. Fisken Hav. 1970, 21-25.

Cowey, C. B., Adron, J. W.; Brark, A. \& Pope, J., 1970. The growth of O-group plaice on artificial diets containing different levels of protein. Helgoländer wiss. Meeresunters. 20, $602-609$.

Figueras, A., 1970. Flat oyster cultivation in Galicia. Helgoländer wiss. Meeresunters. 20, $480-485$.

Fonds, M., 1970. Remarks on the rearing of gobies (Pomatoschistus minutus and P. lozanoi) for experimental purposes. Helgoländer wiss. Meeresunters. 20, 620-628.

FujIYA, M., 1970. Oyster farming in Japan. Helgoländer wiss. Meeresunters. 20, 464-479.

GRUfFydd, Lx. D. \& BeAumont, A. R., 1970. Determination of the optimum concentration of eggs and spermatozoa for the production 'of normal larvae in Pecten maximus (Mollusca, Lamellibranchia). Helgoländer wiss. Meeresunters. 20, 486-497. 
HARAdA, T., 1970. The present status of marine fish cultivation research in Japan. Helgoländer wiss. Meeresunters. 20, 594-601.

LING, S. W., 1967. Feeds and feeding of warm water fishes in ponds in Asia and the Far East. FAO Fish. Rep. 44 (3), 291-309.

McNerli, W. J., (Ed.) 1970. Marine Aquiculture. Oregon State Univ. Press, Corvallis, Oreg. $172 \mathrm{pp}$.

Odum, W. E., 1970. Utilization of the direct grazing and plant detritus food chains by the striped mullet Mugil cephalus. In: Marine food chains. Ed. by J. H. STEELE. Oliver \& Boyd, Edinburgh, 222-240.

Rice, A. L. \& Williamson, D. I., 1970. Methods for rearing larval decapod Crustacea. Helgoländer wiss. Meeresunters. 20, 417-434.

SASTRY, A. N., 1970. Culture of brachyuran crab larvae using a re-circulating sea water system in the laboratory. Helgoländer wiss. Meeresunters. 20, 406-416.

Shelbourne, J. E., 1970. Marine fish cultivation: Priorities and progress in Britain. In: Marine Aquiculture. Ed. by W. J. McNerL. Oregon State Univ. Press, Corvallis, Oreg. $15-36$.

Vallet, F., Berhaut, J., Leray, C., Bonnet, B. \& Pic, P., 1970. Preliminary experiments on the artificial feeding of Mugilidae. Helgoländer wiss. Meeresunters. 20, 610-619.

W länder wiss. Meeresunters. 20, 514-525.

WeBbER, H. H., 1968. Mariculture. BioScience, Wash. 18, 940-945.

- 1970. The development of a maricultural technology for the penaeid shrimps of the Gulf and Carribean Region. Helgoländer wiss. Meeresunters. 20, 455-463.

\section{LIST OF PARTICIPANTS}

Adron, J., NERC Fisheries Biochemical Unit, University of Aberdeen, St. Fittick's Road; Torry, Aberdeen, Scotland.

Battaglia, B., Istituto di Biologia del Mare, Consiglio Nazionale delle Ricerche, Riva Sette Martiri, $1364 \mathrm{~A}$; Venezia, Italy.

BAYNe, B., School of Biology, Leicester University, University Road; Leicester, England.

Bell, M. G., White Fish Authority, Marine Fish Cultivation Unit; West Kilbride, Ayrshire, Scotland.

Berhaut, J., Faculté des Sciences de Marseille, Station Marine d'Endoume, Rue de la Batterie des Lions; Marseille 7e, France.

Bernard, M., Institut Océanographique d'Alger, Jetée Nord; Alger, Algeria.

Bernhard, M., Laboratorio Contaminazione Mare, CNEN-EURATOM; Fiascherino-La Spezia, Italy.

Björnberg, T., Departamento de Zoologia, Universidade de São Paulo, Caixa Postal 8105; São Paulo, Brazil.

Blaxter, J. H.. S., Natural History Department, Marischal College, University of Aberdeen; Aberdeen, Scotland.

BøHLE, B., Fiskeridirektoratets Havforskningsinstitutt, Nordnesparken 2; Bergen, Norway.

Boletzky, M. V. v., Laboratoire Arago; Banyuls-sur-Mer, France.

Boletzkxy, S. v., Laboratoire Arago; Banyuls-sur-Mer, France.

Bookhout, C. G., Duke University, Marine Laboratory; Beaufort, N.C. 28516, USA.

BRAUM, E., Institut für Hydrobiologie und Fischereiwissenschaft der Universität Hamburg; Hamburg 50, Olbersweg 24, FRG.

BüHRINGER, H., Isotopenlabor der Bundesforschungsanstalt für Fischerei; Hamburg 39, Hindenburgstr. 43, FRG.

Caces-Borja, P., Philippine Fisheries Commission, P. O. Box 623; Manila, Philippines.

CASPERS, H., Institut für Hydrobiologie und Fischereiwissenschaft der Universität Hamburg; Hamburg 50, Palmaille 55, FRG.

Costlow, J. D., JR., Duke University, Marine Laboratory; Beaufort, N.C. 28516, USA. 
Cranfield, H. J., Fisheries Research Division; Wellington, New Zealand.

Danielssen, D. S., Statens Biologiske Stasjon Flødevigen; Arendal, Norway.

Dannevig, G., Statens Biologiske Stasjon Flødevigen; Arendal, Norway.

Davis, W. P., Aquatic Sciences Inc., 2624 N.W. 2nd Avenue; Boca Raton, Fla. 33432, USA.

Dohrn, P., Stazione Zoologica; Napoli, Italy.

Figuerredo, M. J. De, Instituto de Biologia Maritima, Cais de Sodrè; Lisboa-2, Portugal.

Frgueras, A., Instituto de Investigaciones Pesqueras, Avda. Orillamar 47; Vigo, Spain.

FuÜCHTER, J., Biologische Anstalt Helgoland, Meeresstation; Helgoland, FRG.

Fonds, M., Nederlands Instituut voor Onderzoek de Zee, Nieuwediep 27; Den Helder, Netherlands.

FreYtaG, G., Bundesforschungsanstalt für Fischerei, Institut für Fangtechnik; Hamburg 50, Palmaille 9, FRG.

FuJIYA, M., The Nansei Regional Fisheries Research Laboratory; Ujina, Hiroshima, Japan.

Groot, S. J. DE, Rijksinstituut voor Visserij-Onderzoek, Haringkade 1; IJmuiden, Netherlands.

Grurfydd, L. D., University College of North Wales, Marine Science Laboratories; Menai Bridge, Anglesey, North Wales.

Guyomarc'H, J.-P., Laboratoire de Biologie Animale, Faculté des Sciences, Avenue le Gorgeu; Brest, France.

Hanks, J. E., Office of Naval Research, Branch Office London, Keysign House, 429 Oxford Street; London W. 1, England.

Harada, T., Fisheries Laboratory of Kinki University, Shirahama-cho, Kogaura 3153; Nishimurogun, Wakayamaken, 649-22, Japan.

Helfrich, P., Hawaii Institute of Marine Biology, University of Hawaii, P. O. Box 1067; Kaneohe, Hawaii 96744, USA.

Hempex, G., Institut für Meereskunde an der Universität Kiel; Kiel, Niemannsweg 11, FRG.

Howell, B. R., Ministery of Agriculture, Fisheries and Food, Marine Hatchery, Breakwater Road; Port Erin, Isle of Man.

Hueck-v, D. Plas, E. H., Economical Technical Department TNO, Koningin Marialaan 21; Den Haag, Netherlands.

JATZKE, P., Biologische Anstalt Helgoland, Meeresstation; Helgoland, FRG.

Jordan, R., Niedersächsisches Landesamt für Bodenforschung; Hannover-Buchholz, AlfredBentz-Haus, FRG.

Kalber, F. A., Aquatic Sciences Inc., 2624 N.W. 2nd Avenue; Boca Raton, Fla. 33432, USA.

Kathurria, J., Biologische Anstalt Helgoland, Meeresstation; Helgoland, FRG.

KensLer, C., Bureau of Commercial Fisheries, Biological Laboratory; West Boothbay Harbor, Maine 04575, USA.

KtöcrNer, K., Biologische Anstalt Helgoland, Meeresstation; Helgoland, FRG.

KöNıG, D., Landesamt für Wasserwirtschaft Schleswig-Holstein; Kiel, Düsternbrooker Weg 104/108, FRG.

Koops, H., Bundesforschungsanstalt für Fisdherei, Institut für Küsten- und Binnenfischerei; Hamburg 50, Palmaille 9, FRG.

Kossmann, K., Frankfurt a. M., Unterlindau 20, FRG.

Kristensen, I., Nederlands Instituut voor Onderzoek der Zee, Nieuwe Diep 27; Den Helder, Netherlands.

Lahaye, J., Laboratoire de Biologie Animale, Faculté des Sciences, Avenue le Gorgeu; Brest, France.

LaUCKNer, G., Biologische Anstalt Helgoland, Zentrale; Hamburg 50, Palmaille 9, FRG.

Ledoux, O., Faculté des Sciences de Paris, Océanographie Biologique, 1 Rue Alfred Bruneau; Paris $16^{\circ}$, France.

LEE, J. W., Marine Biological Station; Port Erin, Isle of Man.

Le Pennec, M., Laboratoire de Zoologie, Faculté des Sciences, Avenue le Gorgeu; Brest, France.

Leray, C., Faculté des Sciences de Marseille, Station Marine d'Endoume, Rue de la Batterie des Lions; Marseille 7e, France. 
Lucas, A., Laboratoire de Zoologie, Faculté des Sciences, Avenue le Gorgeu; Brest, France. MoOdIE, C. F., Department of Oceanography, University of Southampton, University Road; Southampton, England.

Morawa, F., Landwirtschaftskammer Hannover, Fischereireferat; Hannover, Johannsenstr. 10, FRG.

NAssogne, A., Laboratorio Contaminazione Mare, CNEN-EURATOM; Fiascherino - La Spezia, Italy.

Nellen, W., Institut für Meereskunde an der Universität Kiel; Kiel, Niemannsweg 11, FRG.

Otrver, M., Instituto Español de Oceanografia, Alcalá 27; Madrid, Spain.

Persoone, G., Rijksuniversiteit Gent, Laboratorium voor Oecologie, Ledeganckstraat 35; Gent, Belgium.

PeTERs, N., Institut für Hydrobiologie und Fischereiwissenschaft der Universität Hamburg; Hamburg 50, Olbersweg 24, FRG.

Provenzano, A. J., Jr., Institute of Marine Sciences, University of Miami, 10 Rickenbacker Causeway; Miami, Fla. 33149, USA.

Provenzano, A. N. Institute of Marine Sciences, University of Miami, 10 Rickenbacker Causeway; Miami, Fla. 33149, USA.

Rice, A. L., British Museum (Natural History), Cromwell Road; London S. W. 7, England.

Rosenthai, H., Biologische Anstalt Helgoland, Zentrale; Hamburg 50, Palmaille 9, FRG.

RUмoнr, H., Institut für Meereskunde an der Universität Kiel; Kiel, Hohenbergstr. 2, FRG.

SASTRY, A. N., Graduate School of Oceanography, University of Rhode Island; Kingston, R.I. 02881, USA.

Schnetter, R., Botanisches Institut der Universität Gießen; Gießen, Senckenbergstr, 17-21, FRG.

Schumann, K.-H., Biologische Anstalt Helgoland, Meeresstation; Helgoland, FRG.

SEREne, P., Companie des Salins du Midi et des Salines de l'Est, Salin de Villeroy; Sete, France.

SEridjI, R., Institut Océanographique d'Alger, Jetée Nord; Alger, Algeria.

Solemdal, P., Fiskeridirektoratets Havforskninginstitutt, Nordnesparken 2; Bergen, Norway.

Tesch, F.-W., Biologische Anstalt Helgoland, Zentrale; Hamburg 50, Palmaille 9, FRG.

TIEws, K., Bundesforschungsanstalt für Fischerei, Institut für Küsten- und Binnenfischerei; Hamburg 50, Palmaille 9, FRG.

Tranter, D., Indian Ocean Biological Centre, Pullepady Cross Road; Enakulum, Cochin-18, India.

Tverte, S., Statens Biologiske Stasjon Flødevigen; Arendal, Norway.

Vallet, F., Faculté des Sciences de Marseille, Station Marine d'Endoume, Rue de la Batterie des Lions; Marseille $7 \mathrm{e}$, France.

WaLDEN, H., Deutsches Hydrographisches Institut; Hamburg 4, Bernhard-Nocht-Str. 78, FRG.

Walne, P., Fisheries Experiment Station, Castle Bank; Conway, Caernarvonshire, Wales.

Webrer, H. H., Groton Associates, Inc., Hollis Street; Groton, Mass. 01450, USA.

Wrckstead, J. H., Marine Biological Association, The Laboratory, Citadel Hill; Plymouth, England.

Wirliamson, D. I., Marine Biological Station; Port Erin, Isle of Man.

ZATTERA, A., Laboratorio Contaminazione Mare, CNEN-EURATOM; Fiascherino - La Spezia, Italy. 